\title{
Synthesis and Characterization of Natural fibers Reinforced Fiber Epoxy Composites
}

\author{
U. MAHABOOB BASHA ${ }^{1}$, D. MOHANA KRISHNUDU ${ }^{2}$, P. HUSSAIN ${ }^{2}$, \\ K. MANOHAR REDDY ${ }^{3}$, N. KARTHIKEYAN ${ }^{3}$, M. ASHOK KUMAR ${ }^{4^{*}}$ \\ ${ }^{1}$ Department of Mechanical Engineering, AVR \& SVR Engineering College, Kurnool, \\ Andhra Pradesh, India \\ ${ }^{2}$ Department of Mechanical Engineering, AVR \& SVR Engineering College, Kurnool, \\ Andhra Pradesh, India \\ ${ }^{3}$ Department of Mechanical Engineering, PVKK Institute of Technology Anantapuramu, \\ Andhra Pradesh-515001 \\ ${ }^{4}$ Department of Mechanical Engineering, Dr.KV Subba Reddy Engineering College, \\ Kurnool, Andhra Pradesh, India \\ *E-mail address: ashokkumarmala7@gmail.com
}

Keywords: treated Sacharum offinarum; Pennisetum typhoides; Fillet miller

\begin{abstract}
In the current work epoxy resin is chosen as matrix, treated Sacharum offinarum (SugarCane) fiber, Pennisetum typhoides (Jowar)/ Fillet miller (Ragi) filler are chosen as reinforcement. Room temperature cured Epoxy System filled with Sacharum offinarum fiber and Pennisetum typhoides (Jowar)/ Fillet miller (Ragi) filler are synthesised by mechanical shear mixer, then kept in a Ultra sonic Sonicator for better dispersion of Pennisetum typhoides (Jowar)/ Fillet miller (Ragi) filler in the matrix. Different weights of modified Pennisetum typhoides (Jowar)/ Fillet miller (Ragi) filler (1,2,3,4,5 gm wt) has been incorporated into the Epoxy matrix in order to study the variation of Mechanical and Thermal properties.

Mechanical properties like Flexural strength, Tensile strength and impact strength of the micro hybrid composite are studied by UTM (Universal Testing Machine). Thermal properties of micro hybrid composites are studied using Thermo Gravimetric Analysis (TGA) and Differential Scanning Calorimetry (DSC).
\end{abstract}

\section{INTRODUCTION}

Thermoplastics occupy only a small percentage of the advanced composite market, while other and epoxy thermoset materials contribute to more than 70 per cent. Epoxy resins the most important matrix polymer when it comes to high performance. Its combination with natural fibers gives an advanced composite with properties like low weight, good mechanical properties and tribological properties. These materials make very attractive for use in aerospace applications. A rough estimate has it that for every unit of weight reduction in aircraft, there is a considerable less considerable fuel consumption or higher load capacity and hence material offers material saving. Due to low density around $1.3 \mathrm{~g} / \mathrm{cm} 3$, good adhesive and mechanical properties, epoxy resins become a promising material for in the transportation industry, usually in the form of composite materials. The performance of these composites not only depends on the selection of its components, but also on the interface between fiber and resin. Sometimes it is necessary to modify the matrix and reinforcement for specific properties.

Due to low density natural fibres are widely used as reinforcing agent as it is high biodegradability. Natural fibers are largely divided into two categories depending on their origin: plant based and animal based. Therefore, natural fiber can serve as reinforcements by improving the strength and stiffness and also reducing the weight of resulting biocomposite materials, although the properties of natural fibers vary with their source and treatments. 
The Fiber / Filler reinforced composites improve strength, fatigue, stiffness and strength to weight ratio by incorporating strong, stiff, brittle Fibers into a softener, more ductile matrix. The matrix material transmits the force to the Fibers and provides ductility and toughness.

\section{MATERIALS AND METHODS}

Materials: Commercially available epoxy (LY-556) and hardener (HY-951) supplied by Ciba-Geigy India Ltd. Company. Naturally available sugar cane fibers were retrieved from Regadikothuru village, Anantapur, Andhra Pradesh, India. In addition, naturally available jowar /Ragi are used as filler is also retrieved from Regadikothuru village, Anantapur, Andhra Pradesh, India.

Fiber Treatment: Sugar cane fiber was taken in a plastic tray and a $5 \% \mathrm{NaOH}$ solution was added into the tray and the fibers were allowed to soak in the solution for $1 \mathrm{hr}$. The fibers were then washed thoroughly with water to remove the excess of $\mathrm{NaOH}$ sticking to the fibers. Final washing was carried out with distilled water and the fibers were then dried in hot air

Composite Manufacturing: Moulds are prepared for different castings that are made from resin as per ASTM standards. The pre - calculated amount of Jowar/Ragi and Epoxy (resin) is mixed together in suitable beaker. Jowar/Ragi is mixed with stipulated quantity of resin based on the predetermined ratio and mixed thoroughly with mechanical shear mixing for about 1 hour at ambient temperature conditions. Then the mixer is carried out through a high intensity ultraSonicator for one and half hour with pulse mode (50s on / 25s off). External cooling system is employed to avoid temperature during the sonication process, by submerging the beaker containing the mixer in an ice bath. Once the irradiation is completed, hardener is added to the modified epoxy in the ratio of 10:1 parts by weight. A glass mould with required dimensions is

use for making sample as per the ASTM standards and it is coated with mould releasing agent enabling easy removal of the sample. In this technique sugar cane fiber is wetted by a thin layer of epoxy/ jowar/Ragi and epoxy suspension in a mould. Stacking of sugar cane fiber is carefully arranged side by side all over the mould. Stacking of sugar cane fiber is carefully arranged after pouring some amount of resin against the mould, to keep the poor impregnation at bay. Left over quantity of mixture is poured over the sugar cane fiber. Brush and roller are used to impregnate fiber. The closed mould is kept under the pressure for 24 hours at room temperature. To ensure complete curing, the composite samples are post cured at $70^{\circ} \mathrm{C}$ for 1 hour and the test specimens of the required size is cut out from the sheet. The removed castings are cut into the samples in accordance with ASTM standards for further testing. Direct processing technique has been used for the above micro hybrid composites preparation.

Mechanical Tests: In the present research work, specimens are prepared to study various tests which include tensile test, impact test and flexural test. In fact, all these samples are cut as per ASTM standards. Test specimens ASTM D638 for tensile test of dimensions of $(100 \times 20 \times 3) \mathrm{mm}^{3}$, ASTMD618 for flexural test of dimensions of $(100 \times 20 \times 3) \mathrm{mm}^{3}$ and ASTMD695 for impact test of dimensions of $(150 \times 150 \times 3) \mathrm{mm}^{3}$. In each case, samples were tested on UTM and its values are tabulated in the following table1.

Thermal analysis: The thermal characteristics of the epoxy/hybrid composites were measured using both Differential Scanning Calorimetry (DSC) and thermo gravimetric Analyses (TGA) at a rate of $10^{\circ} \mathrm{C} / \mathrm{min}$ under nitrogen flow. 
Table 1: Tensile strength, flexural strength and impact strength of treated sugar cane and epoxy/jowar hybrid composites with different proportions.

\begin{tabular}{|c|c|c|c|c|c|}
\hline Sample (wt.\%) & $\begin{array}{c}\text { Tensile } \\
\text { strength } \\
\text { (MPa) }\end{array}$ & $\begin{array}{c}\text { Tensile } \\
\text { Modulus } \\
\text { (GPa) }\end{array}$ & $\begin{array}{c}\text { Flexural } \\
\text { Strength } \\
\text { (MPa) }\end{array}$ & $\begin{array}{c}\text { Flexural } \\
\text { Modulus } \\
\text { (GPa) }\end{array}$ & $\begin{array}{c}\text { Impact } \\
\text { strength } \\
\text { (J/Cm) }\end{array}$ \\
\hline EP & 25.32 & 1.135 & 35.25 & 2.452 & 40.69 \\
\hline $\begin{array}{c}\text { EP+SCF(10\%)+ } \\
(\mathbf{1 \% )} \text { jowar flour }\end{array}$ & 36.48 & 1.457 & 42.68 & 4.895 & 42.56 \\
\hline $\begin{array}{c}\text { EP+SCF(10\%)+ } \\
(\mathbf{2 \% )} \text { jowar flour }\end{array}$ & 39.14 & 1.536 & 45.68 & 4.968 & 43.56 \\
\hline $\begin{array}{c}\text { EP+SCF(10\%)+ } \\
\text { (3\%) jowar flour }\end{array}$ & 40.15 & 1.689 & 46.05 & 5.025 & 44.52 \\
\hline $\begin{array}{c}\text { EP+SCF(10\%)+ } \\
\text { (4\%) jowar flour }\end{array}$ & 42.69 & 1.956 & 45.78 & 3.245 & 45.86 \\
\hline $\begin{array}{l}\text { EP+SCF(10\%)+ } \\
\text { (5\%) jowar flour }\end{array}$ & 36.96 & 1.969 & 45.36 & 3.125 & 35.05 \\
\hline \multicolumn{7}{|l|}{ EP=Epoxy; SCF=sugarcane fiber } \\
\hline
\end{tabular}

Table 2: Tensile strength, flexural strength and impact strength of treated sugar cane and epoxy/Ragi hybrid composites with different proportions.

\begin{tabular}{|c|c|c|c|c|c|}
\hline Sample (wt.\%) & $\begin{array}{c}\text { Tensile } \\
\text { strength } \\
\text { (MPa) }\end{array}$ & $\begin{array}{c}\text { Tensile } \\
\text { Modulus } \\
\text { (GPa) }\end{array}$ & $\begin{array}{c}\text { Flexural } \\
\text { Strength } \\
\text { (MPa) }\end{array}$ & $\begin{array}{c}\text { Flexural } \\
\text { Modulus } \\
\text { (GPa) }\end{array}$ & $\begin{array}{c}\text { Impact } \\
\text { strength } \\
\text { (J/Cm) }\end{array}$ \\
\hline EP & 25.32 & 1.135 & 35.25 & 2.452 & 40.69 \\
\hline $\begin{array}{c}\text { EP+SCF(10\%)+ } \\
\text { (1\%)Ragi flour }\end{array}$ & 37.56 & 1.568 & 35.26 & 2.765 & 43.56 \\
\hline $\begin{array}{c}\text { EP+SCF(10\%)+ } \\
\text { (2\%)Ragi flour }\end{array}$ & 38.61 & 1.695 & 42.25 & 2.986 & 45.78 \\
\hline $\begin{array}{c}\text { EP+SCF(10\%)+ } \\
(\mathbf{3 \% ) ~ R a g i ~ f l o u r ~}\end{array}$ & 39.11 & 1.745 & 43.65 & 3.146 & 49.15 \\
\hline $\begin{array}{c}\text { EP+SCF(10\%)+ } \\
\text { (4\%) Ragi flour }\end{array}$ & 41.02 & 1.345 & 44.21 & 3.369 & 50.63 \\
\hline $\begin{array}{c}\text { EP+SCF(10\%)+ } \\
\text { (5\%)Ragi flour }\end{array}$ & 34.14 & 1.427 & 45.78 & 3.895 & 52.36 \\
\hline \multicolumn{7}{|l|}{$\mathrm{EP=Epoxy;} \mathrm{SCF=sugarcane} \mathrm{fiber}$} \\
\hline
\end{tabular}

\section{Flexural Strength(mpa)}

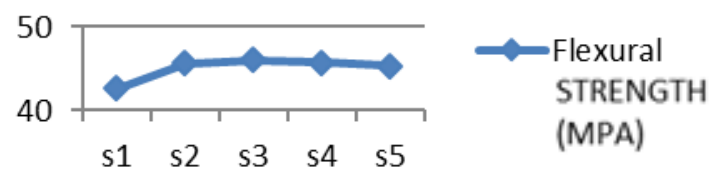

Fig 1: Flexural strength variations for different proportions of jowar 


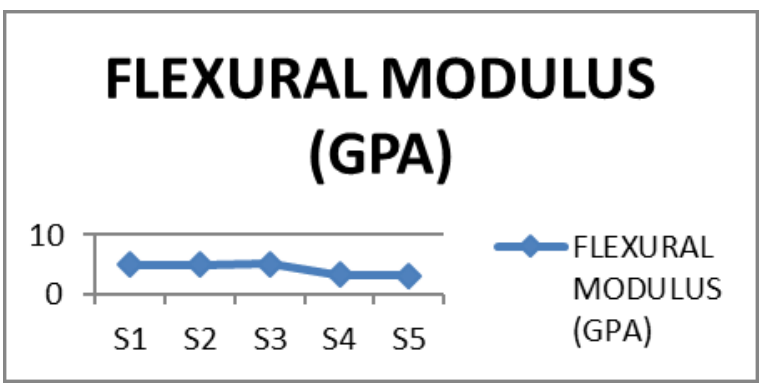

Fig 2: Flexural modulus variations for different proportions of jowar

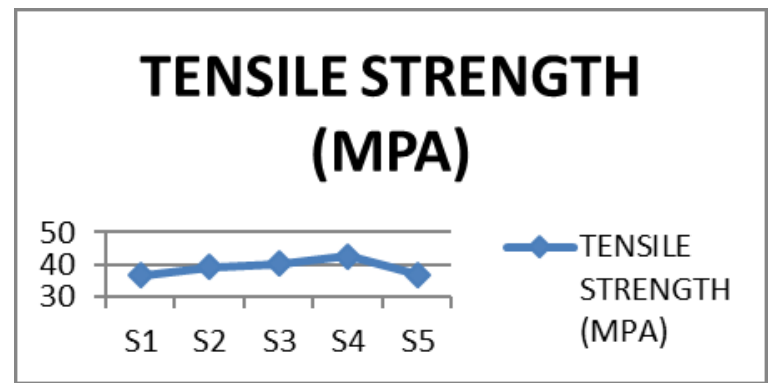

Fig 3: Tensile strength variations for different proportions of jowar

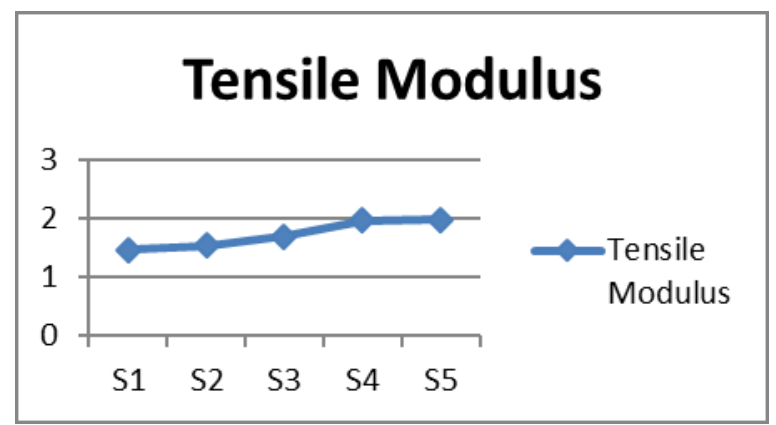

Fig 4: Tensile modulus variations for different proportions of jowar

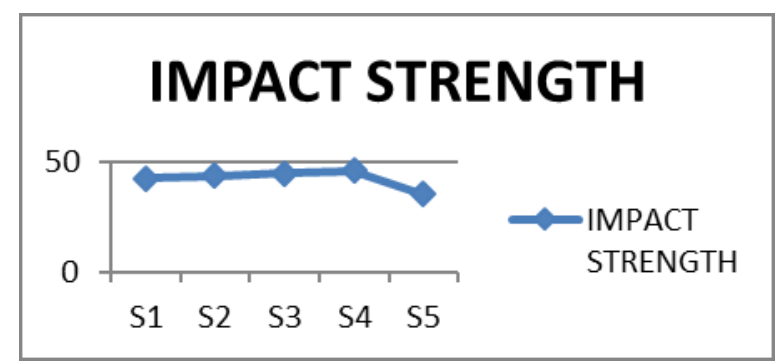

Fig 5: Impact strength modulus variations for different proportions of jowar

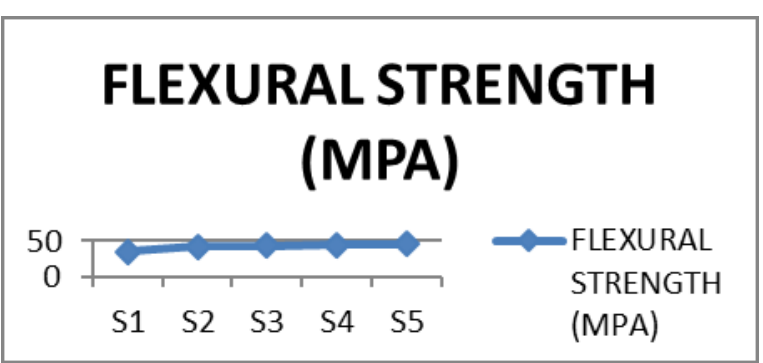

Fig 6: Flexural strength variations for different proportions of Ragi 


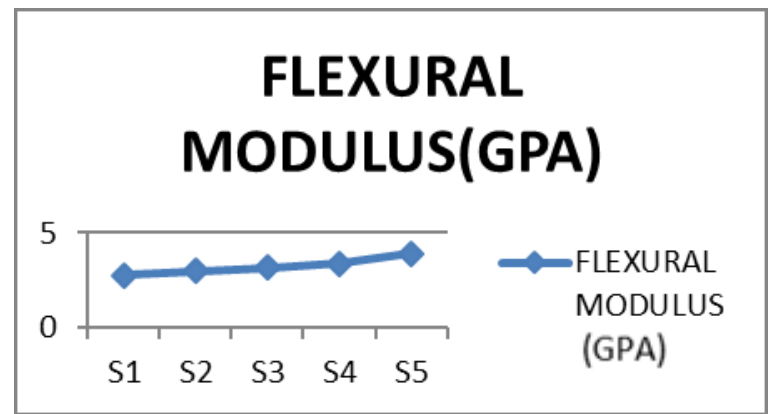

Fig 7: Flexural modulus variations for different proportions of Ragi

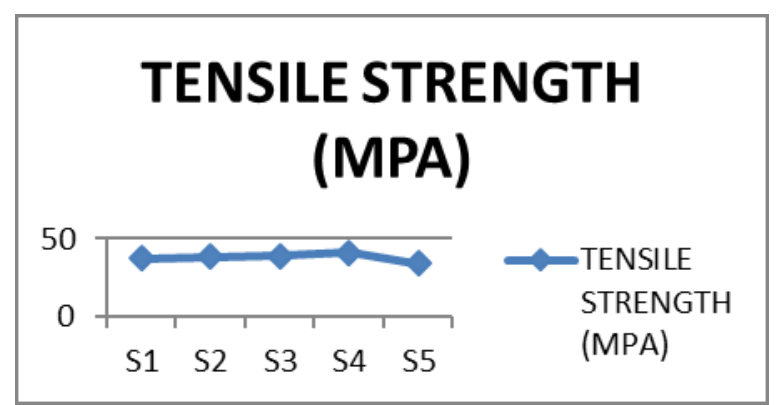

Fig 8: Tensile strength variations for different proportions of Ragi

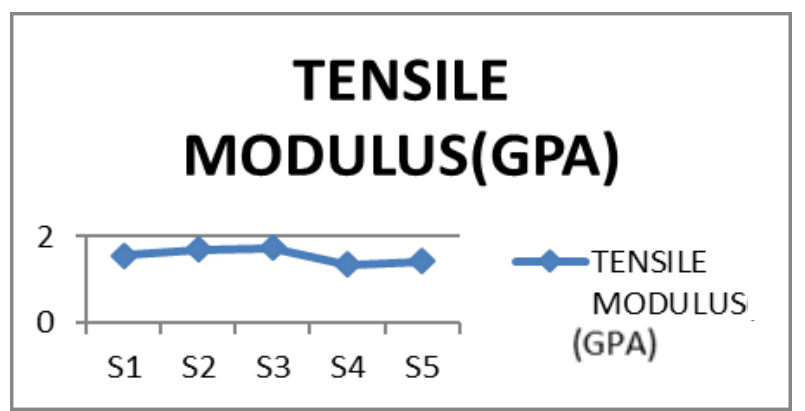

Fig 9: Tensile modulus variations for different proportions of Ragi

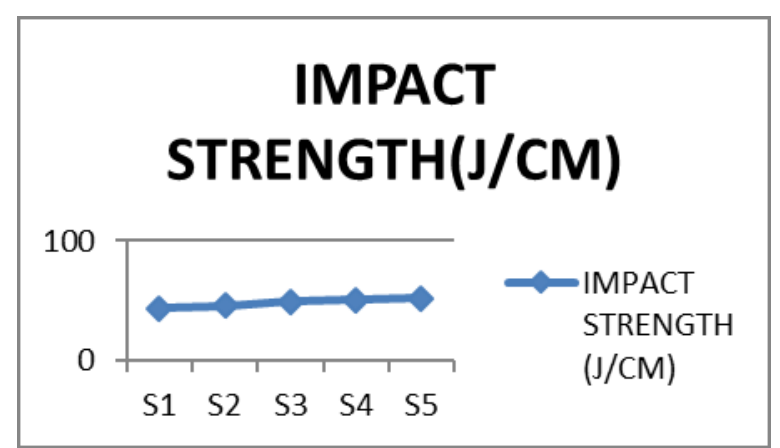

Fig 10: Impact strength variations for different proportions of Ragi

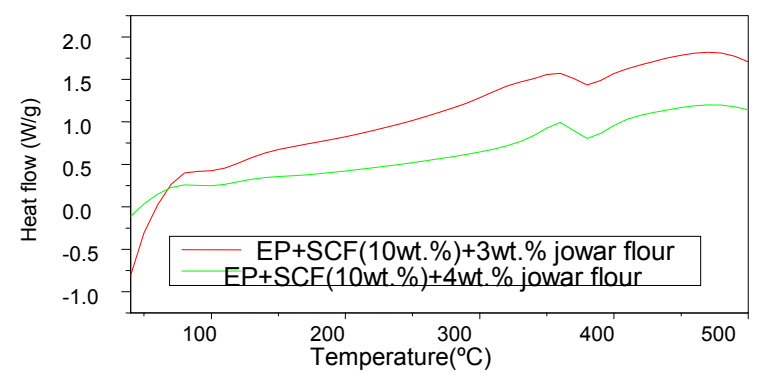

Fig 11: Differential Scanning Calorimetry (DSC) for Specimen 3 and Specimen 4 of jowar 


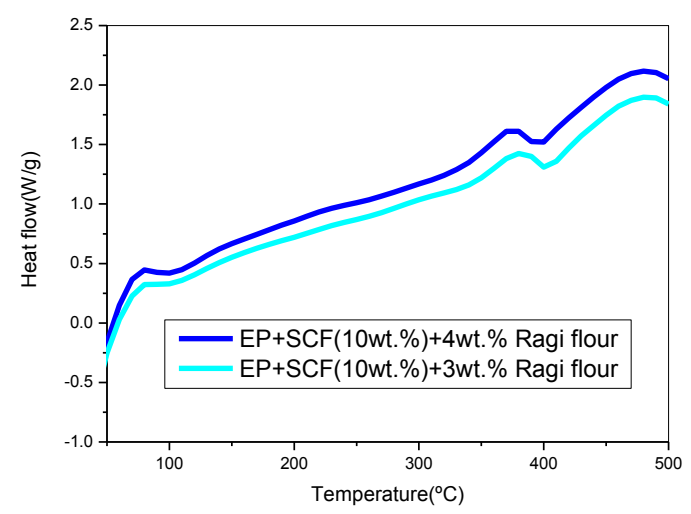

Fig 12: Differential Scanning Calorimetry (DSC) for Specimen 3 and Specimen 4 of Ragi

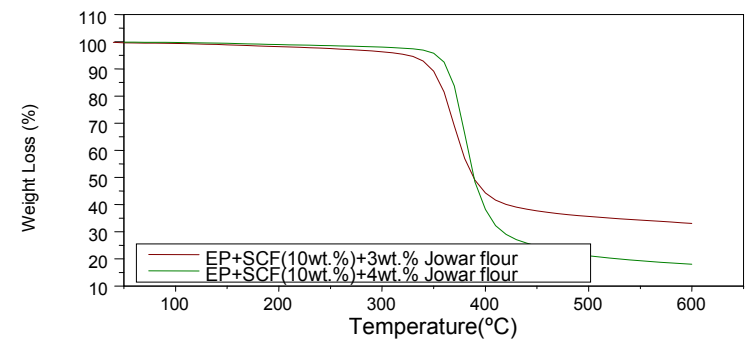

Fig 13: Thermo Gravimetric Analysis for Specimen 3 and Specimen 4 of jowar

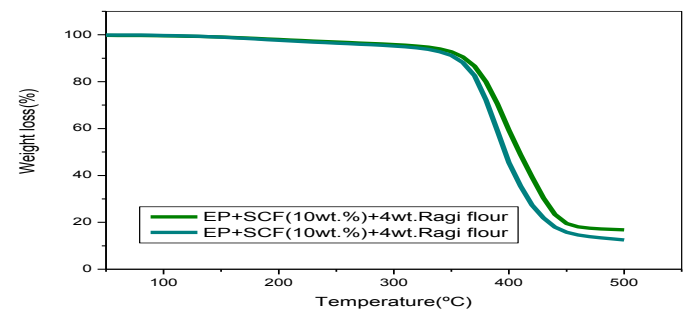

Fig 14: Thermo Gravimetric Analysis for Specimen 3 and Specimen 4 of Ragi

\section{RESULTS AND DISCUSSIONS:}

\section{Mechanical Characterization:}

Experimental results of epoxy hybrid (treated sugar cane and jowar/Ragi) composites are prepared with different proportions. It is obvious strength increases when increasing jowar upto $3 \mathrm{gm}$ impregnated with epoxy matrix and up to $4 \mathrm{gm}$ for ragi. Mechanical properties (i.e. tensile, flexural and impact) increased when epoxy matrix impregnated with $2 \mathrm{gm}$ fiber of each as mentioned above [1\&2]. Mechanical properties are degraded when jowar is further increased. It is observed that $3 \mathrm{gm}$ jowar composites were optimal tensile, flexural and impact strength than the other proportions of jowar composites and also for ragi. Figures 1-10, represents graphical variations on tensile, flexural, and impact strength properties as function of sugar cane fiber and epoxy/jowar and epoxy/Ragi. Thus, it is observed that the mechanical properties are degraded due to further increase in jowar weight and mechanical properties are increased by further increase in Ragi weight but here our main intention is that as much as possible we has to decrease weight of the composite. 


\section{Thermal Analysis:}

Differential Scanning Calorimetric (DSC) analysis is done to the epoxy filled with jowar/Ragi \& sugar cane fiber reinforced composites. From fig 11-12 it is observed that both the composites specimen3 (epoxy $(50 g m)+$ jowar(3gm) +sugar cane fiber $(2 \mathrm{gm})$ and specimen 4 (epoxy $(50 \mathrm{gm})+$ ragi $(4 \mathrm{gm})+$ sugar cane fiber $(2 \mathrm{gm})$ properties degrade as the heat flow and temperature increases. specimen 3 has the higher glass transition temperature $100^{\circ} \mathrm{C}$ in jowar compared to specimen 4 $50^{\circ} \mathrm{C}$ in ragi. Hence specimen 3 in jowar has more durability compared to specimen 4 in Ragi.

Thermo Gravimetric Analysis is observed From the Figure 13-14 it is observed that the system 1 specimen 3 (Epoxy $(50 \mathrm{gm})+$ jowar $(3 \mathrm{gm})+$ sugar cane fiber $(2 \mathrm{gm}))$ can resist up to $350^{\circ} \mathrm{C}$. The weight loss takes place above $350^{\circ} \mathrm{C}$. The system 2 specimen $4($ Epoxy $(50 \mathrm{gm})+$ ragi $(4 \mathrm{gm})+$ sugar cane $(2 \mathrm{gm})$ can resist up to $250^{\circ} \mathrm{C}$. The weight loss takes place above $250^{\circ} \mathrm{C}$. The system 1 specimen 3 has good thermal stability compared to system 2 specimen 4 .

\section{CONCLUSION:}

The mechanical properties (tensile, flexural and impact) properties of Epoxy filled with jowar and sugar cane fiber reinforced hybrid composites is higher than the Epoxy filled with Ragi and Sugar cane fiber reinforced composites. Epoxy (50gm) filled with Jowar (3gm) and Sugar cane fiber (2gm) reinforced hybrid composite showed remarkable improvement in flexural strength and flexural modulus . The Thermal properties of Epoxy filled Jowar and Sugar cane fiber reinforced hybrid composites are higher than the Epoxy filled Ragi and Sugar cane fiber reinforced composites. Both the Jowar and ragi are well dispersed in the epoxy. System1 Specimen 3 (Epoxy $(50 \mathrm{gm})+$ jowar $(3 \mathrm{gm})+$ Sugar cane fiber $(2 \mathrm{gm})$ has high glass transition temperature. Both system1 (Epoxy filled with Jowar and Sugar cane fiber reinforced composites) and system2(Epoxy filled with Ragi and Sugar cane fiber reinforced hybrid composites) can be used in reverse engineering process. System 1 composites are more efficient. It can be used in the manufacture of automobile fuel tanks, car doors, aero plane wings and also in high strength to less weight applications.

\section{References:}

[1] Ashok Kumar, M., Ramachandra Reddy, G., Siva Bharathi, Y., Venkata Naidu, S. and Naga Prasad Naidu, V. (2010). Frictional Co-efficient, Hardness, Impact Strength, and Chemical Resistance of Reinforced Sisal/Glass Fiber Epoxy Hybrid Composites, Journal of Composite Materials, (accepted).

[2] Venkata Reddy, G., Venkata Naidu, S. and Shobha Rani, T. (2008).Kapok/Glass Polyester Hybrid Composites: Tensile and Hardness Properties, , Journal of Reinforced Plastics and Composites, 27:1775-1787.

[3] Noorunnisa Khanam, P., Mohan Reddy, M., Raghu, K., John, K. and Venkata Naidu, S.(2007). Tensile, Flexural and Compressive properties of Sisal/Silk Hybrid Composites, Journal of Reinforced Plastics and Composites, 26:1065-1075.

[4] Raghu, K., Noorunnisa Khanam, P. and Venkata Naidu, S. (2008). Chemical Resistance Studies of Silk/Sisal Fibre Reinforced Unsaturated Polyester-Based Hybrid Composites, Journal of Reinforced Plastics and Composites, (xx):1-3.

[5] Venkata Reddy, G., Venkata Naidu, S. and Shobha Rani, T. (2009). A Study on Hardness and Flexural Properties of Kapok/Sisal Composites, Journal of Reinforced Plastics and Composites, 28 : 2035-2044.

[6] Venkata Reddy, G., Venkata Naidu, S. and Shobha Rani, T. (2008).Impact Properties of Kapok Based Unsaturated Polyester Hybrid Composites, Journal of Reinforced Plastics and Composites,27: 1789-1804. 